\title{
Evaluation of some Fodder Beet Genotypes for Yield, Yield Components and Diseases Susceptibility under New Valley Conditions \\ Hamed, N. M. ${ }^{1}$ and M. F. Abdel-Monaim ${ }^{2}$ \\ ${ }^{1}$ Forage Crops Res. Dept., Field Crops Res. Inst. ARC., Giza, Egypt. \\ ${ }^{2}$ Plant Pathology Res. Inst., ARC., Giza, Egypt
}

Corresponding Author: Abdel-Monaim, M. F. Plant Pathology Research Institute, Agricultural Research Center, Giza, Egypt

E-mail: fowzy_2008@yahoo.com

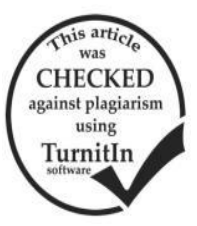

\begin{abstract}
A field experiment was conducted to evaluate four fodder beet genotypes under Farm of El-Kharga Research Station of the Agricultural Research Center New Valley Governorate during two successive growing winter seasons of $2013 / 14$ and 2014/15. The experiment was carried out in a randomized complete block design (RCBD) with three replications. The present investigation focused on the growth and yielding properties and diseases development. The obtained results show that the tested genotypes of fodder beat were significantly different for yield characteristics viz. average of leaf length, root length, number of leaves/plant and root diameter and yield components viz. fresh and dry weight of root and leaves/plant and total fresh and dry weight of root and leaves/fed. Genotype Splendid recorded the highest leaf length, number of leaves /plant, root diameter in both seasons and their combined data, respectively. Also, this genotype recorded the best root fresh weight/plant, total fresh weight of roots/fed and dry weight of roots/fed. in both seasons their combined data, respectively. While genotype Jamon recorded the highest root length, fresh weight of leaves/plant, total fresh weight of leaves / fed. and total dry weight of leaves/fed in both seasons their combined data, respectively. On contrary, Splendid fodder beat genotype recoded the lowest fresh weight of leaves /plant, fresh and dry weight of leaves/fed. While, Jamon recorded the lowest fresh weight of root/plant, fresh and dry weight of roots/fed. The combined analysis of data revealed that the treats leaf length, number of leaves per plant fresh weight of leaves per plant and dry weight of roots per fed were insignificant effect by seasons. While the characters, root length, root diameter, fresh weight of root per plant and fresh weight of roots per fad were significant affected by seasons, whereas the mean values of the second season were more than the first season.On the other hand, the tested genotypes were varied to susceptibility to infection with diseases viz. damping-off, root rot/wilt, powdery mildew and leaf spots under natural infection in field. Both Rigour and Jamon genotypes recorded the highest susceptibility to infection with damping-off disease in both growing seasons, while both genotypes recorded the lowest root rot /wilt severity. Splendid and Rigour genotypes were recorded the highest susceptible to infection with powdery mildew in both growing seasons. Starmon and Splendid genotypes were recorded the highest percentage of infection with leaf spot disease in both growing seasons. We could recommend growing genotype Splendid under New Valley Governorate because recorded the highest results in most parameters and resistance to root rot and wilt diseases.

Keywords: Fodder beet, Genotypes, Yield and yield components, Diseases
\end{abstract}

\section{INTRODUCTION}

Fodder beet offers a higher yield potential than any other "arable" fodder crop. The roots have an excellent feed quality and they are very palatable to ruminant stock. The leaf can be utilized if required to boost the total fodder output even further. Fodder beet when grown under suitable conditions, can produce almost $20 \mathrm{t} \mathrm{ha}^{-1}$ dry matter yield as compared with $13 \pm 1.5 \mathrm{t} \mathrm{DM} / \mathrm{ha}^{-1}$ from four harvests of grass. Approximately $75 \%$ of fodder beet dry matter is in the root component (DAF, 1998).

Including fodder beet in diet of cattle increases intake of dry matter that is quantitative and qualitative factors affecting intake of the basal diet. Fodder beet is successively grown as a fodder crop in the many European countries. The plant is used as a valuable source of fodder for cattle (Niazi et al., 2000 and Slavova et al., 2004). Since fodder beet contains more water and sugar, it increases milk product and being suitable forage for dairy cows. The fodder beet is used by being chopped and by mixing with straw in European countries. It is also reported that the plant is suitable to make silage (Akyildiz, 1983 and Ozen et al., 1993).

The types of the fodder beet varieties are different from each other in terms of some important characteristics such as root shape, root color, root dry matter content, root and leaf yield, proportion of the root above ground (Abdel-Naby et al., 2014). Determination of appropriate genotypes for each region is important for increasing food better farming.

Fodder beet as similar with sugar beet in attacked with many diseases were effecting of root and foliage protection such as damping-off, root crown rots, wilt diseases. Also, Foliar diseases that affecting leaves and stems of the plants constitute one of the most serious groups causing great damage to the crop specially powdery mildew caused by Erysiphe betae (Synonym= Erysiphe polygoni) (Harveson, et al., 2009). And leaf spots caused by Cercospora beticola (Whitney and Duffus, 1986).

In Egypt, no references for diseases of fodder beet are available. Therefore, the objectives of this study were to: 1) evaluate yield and yield components of four genotypes under field conditions in New Valley Governorate and, 2) evaluate the susceptibility of these genotypes to infection with root and foliar diseases under field conditions.

\section{MATERIALS AND METHODS}

This study is conducted in 2013-14 and 2014-15 growing seasons in New Valley Agric. Res. Station. The study was designed to evaluate yield character for four foreign fodder beet genotypes namely Splendid, 
Starmon, Rigour and Jamon introduced from France under field conditions.

An experiment was conducted in a randomized complete block design (RCBD) with three replications. Genotypes were sown in plot size $12 \mathrm{~m}^{2}(4 \mathrm{~m} \times 3 \mathrm{~m})$ with five ridges, $60 \mathrm{~cm}$ apart. Fodder beet seeds of the four studied genotypes were sown with about three seeds per hell on top of the shoulder of the ridge at 30 $\mathrm{cm}$ apart (14 hills per ridge $4 \mathrm{~m}$ long). The sowing done on 15 and 20 October in the first and the second season, respectively. The crop was irrigated at 12-15 days intervals. Hand thinning to one plant per hill after 5 weeks from planting during both seasons. Fertilizers application (NPK) at a mount and rates of recommended package $((200: 150: 150 \mathrm{~kg} / \mathrm{fad})$. The harvesting was done about 7 months from sowing in the two growing seasons. At harvest, 10 plants from the central ridges were pulled up to determine the following traits:

1. Average leaf length (cm per plant).

2. Average root length (cm per plant).

3. Average number of total leaves per plant.

4. Average root diameter (cm per plant) by circumference of circle when the maximum width of root divided on 2.14 .

5. Average fresh weight of root /plant $(\mathrm{kg})$

6. Average fresh weight of leaves /plant $(\mathrm{kg})$

7. Average fresh weight of roots /fad. (Ton)

8. Average dry weight of roots /fad. (Ton)

9. Average fresh weight of leaves /fad. (Ton)

10. Dry weight of leaves /fad. (Ton)

Fresh and dry weight of roots and leaves (ton/ fed.) by weight roots and leaves fresh and dry weight per $\mathrm{kg} / \mathrm{plot}$ and converted and expressed in ton per fed.

\section{Disease Assessments:}

Damping-off, Root Rot and Wilt Assessment:

Percentage of damping-off was recorded 30 days after planting. While severity of root rot / wilt was determined after 120 days according to Abdou et al. (2001) using a rating scale of 0 to 5 on the basis of root discoloration or leaf yellowing as follows, $0=$ neither root discoloration nor leaf yellowing, $1=1-25 \%$ root discoloration or one leaf yellowed, $2=26-50 \%$ root discoloration or more than one leaf yellowed, $3=51$ $75 \%$ root discoloration plus one leaf wilted, $4=$ up to $76 \%$ root discoloration or more than one leaf wilted, and $5=$ completely dead plants. For each replicate a disease severity index (DSI) similar to that one described by Liu et al. (1995) was calculated as follows:

DSI $=\frac{\sum d}{d \max . \times n} \times 100$

Whereas: $d$ is the disease rating possible, $d$ max is the maximum disease rating and $n$ is the total number of plants examined in each replicate.

\section{Powdery Mildew Assessment:}

Powdery mildew disease severity was monitored using 0-5 scale (Akhileshwari et al., 2012), $0=$ No symptom of powdery mildew= Immune; $1=$ Small scattered powdery mildew specks covering 1-10 per cent or less leaf area (Resistant); $2=$ Small powdery lesions covering 11-25 per cent of leaf area (Moderately resistant); 3 = Powdery lesions enlarged covering 26-50 per cent of leaf area (Moderately susceptible); $4=$ Powdery lesions coalesce to form big patches covering 51-75 per cent of leaf area (Susceptible) and $5=$ Big powdery patches covering $>75$ per cent of leaf area and defoliation occur (Highly susceptible). Percent disease index (PDI) was calculated by using the formula given by Wheeler(1969) as follows:

PDI $=\frac{\begin{array}{c}\text { Sum of individual disease } \\ \text { ratings }\end{array}}{\begin{array}{c}\text { Total number of leaves } \\ \text { observed }\end{array}} \times \frac{100}{\begin{array}{c}\text { Maximum disease } \\ \text { grade }\end{array}}$

\section{Cercospora leaf spot Assessment:}

Cercospora leaf spot severity was rated on the KWS scale of 1 to 9 (Weiland, 2000). A rating of 1 indicated no disease, a rating of 3 indicated that all outer leaves displayed typical symptoms and was the early stages of economic loss level and a rating of 9 indicated that the plants had only new leaf growth, all earlier leaves being dead. Cercospora leaf spot severity was assessed throughout the season. However, the rating done three days prior to harvest is reported.

Statistical Analysis:

All experiments were performed twice. Analysis of variance was carried out using MSTAT-C, 1991 program version 2.10. Least significant difference (LSD) was employed to test for significant difference between treatments at $\mathrm{P} \leq 0.05$ (Gomez and Gomez, 1984).

\section{RESULTS AND DISCUSSION}

\section{Evaluation of fodder beat genotypes for yield and yield components:}

Mean performances of four genotypes of fodder beat in the two seasons and their combined for forage characters were determined and the obtained results presented in Table 1. The means showed that fodder beat genotypes appeared to be varied significantly from character to another, (Abdel- Naby et al., 2014).

The differences between the genotypes were significant at $(\mathrm{p}=0.05)$ for yield and yield components in both seasons and their combined data. Splendid genotype was the highest of leaf length $(35.72,36.63$ and $36.18 \mathrm{~cm})$, number of leaves per plant $(34.60,33.15$ and 33.88 leaf/plant), root diameter $(15.20,16.23$ and $15.72 \mathrm{~cm})$, fresh weight of root/plant $(2.67,2.96$ and $2.82 \mathrm{~kg}$ ), fresh weight of roots/fad. (47.87, 50.14 and 49.01 ton) and dry weight of roots/fad. (5.98, 5.98 and 5.98 ton) in both seasons and their combined data, respectively. On contrary, splendid fodder beat genotype recorded the lowest values of root length, fresh weight of leaves/plant, fresh and dry weight of leaves/fad. In the two seasons and their combined data.

While, Jamon fodder beat genotype recorded the lowest mean values of leaf length $(30.62,30.98$ and $30.80 \mathrm{~cm})$, number of leaves/plant $(13.80,15.49$ and $14.65 \mathrm{~cm})$, root diameter $(13.00,12.96$ and $12.98 \mathrm{~cm})$, fresh weight of root/plant $(2.29,2.36$ and $2.33 \mathrm{~kg})$, fresh weight of roots/fad. (29.53, 30.14 and 29.84 ton) and dry weight of roots/fad (4.15, 4.22 and 4.19 ton) in the two seasons and their combined data, respectively, the same results were obtained by Abdel-Naby, et al. 
(2014). On the other hand, Jamon fodder beat genotype recorded the highest mean values of root length (31.67, 34.49 and $33.08 \mathrm{~cm})$, fresh weight of leaves/plant $(0.89$, 0.83 and $0.86 \mathrm{~kg}$ ), fresh weight of leaves/fad. (14.23, 14.25 and 14.24 ton) and dry weight of leaves/fad. (2.17, 2.39 and 2.28 ton) in the two seasons, respectively. The data revealed that stem diameter and root weight were the highest effect on root yield per faddan as well as, leaf length and number of leaves per plant (Splendid genotype). On contrary, fresh weight of leaves/fad. ,plant disaffected by leaf length or number of leaves per plant, whereas, Jamon fodder beat genotype was the lowest leaf length and number of leaves per plant and produce the highest fresh weight of leaves per plant and per faddan, it is may be due to the leaf thick, whereas, for example, Jamon genotype leaf weight is

Fresh leaves weight/plant Number of leaves/plant $=\quad 890=64.5 \mathrm{gm} / \mathrm{leaf}$,

While splendid genotype was

Table 1. Mean performances of fodder beet genotypes for yield and yield components under field conditions during 2013-14 and 2014-15 growing seasons and their combined data.

\begin{tabular}{|c|c|c|c|c|c|c|c|c|c|c|c|}
\hline \multicolumn{2}{|l|}{ Genotypes } & $\begin{array}{c}\text { Leaf } \\
\text { length } \\
(\mathrm{cm})\end{array}$ & $\begin{array}{c}\text { Root } \\
\text { length } \\
(\mathrm{cm})\end{array}$ & $\begin{array}{c}\text { Number of } \\
\text { leaves } \\
\text { /plant }\end{array}$ & $\begin{array}{c}\text { Root } \\
\text { diameter } \\
(\mathrm{cm})\end{array}$ & $\begin{array}{c}\text { Fresh } \\
\text { weight of } \\
\text { root /plant } \\
(\mathrm{kg}) \\
\end{array}$ & $\begin{array}{c}\text { Fresh } \\
\text { weight of } \\
\text { leaves } \\
\text { /plant (kg) } \\
\end{array}$ & $\begin{array}{c}\text { Fresh } \\
\text { weight of } \\
\text { roots /fad } \\
\text { (Ton) } \\
\end{array}$ & $\begin{array}{c}\text { Dry } \\
\text { weight of } \\
\text { roots /fad } \\
\text { (Ton) } \\
\end{array}$ & $\begin{array}{c}\text { Fresh } \\
\text { weight of } \\
\text { leaves /fad } 1 \\
\text { (Ton) } \\
\end{array}$ & $\begin{array}{c}\text { Dry } \\
\text { weight of } \\
\text { leaves /fad } \\
\text { (Ton) } \\
\end{array}$ \\
\hline \multicolumn{12}{|c|}{ Season 2013-2014 } \\
\hline \multicolumn{2}{|c|}{ Splendid } & 35.72 & 27.33 & 34.60 & 15.20 & 2.67 & 0.45 & 47.87 & 5.98 & 8.00 & 1.01 \\
\hline \multicolumn{2}{|l|}{ Starmon } & 32.71 & 28.20 & 27.73 & 13.37 & 2.31 & 0.75 & 43.81 & 5.07 & 13.36 & 1.69 \\
\hline \multicolumn{2}{|l|}{ Rigour } & 33.04 & 29.80 & 32.20 & 13.20 & 2.49 & 0.65 & 33.00 & 4.75 & 9.62 & 1.69 \\
\hline \multicolumn{2}{|l|}{ Jamon } & 30.62 & 31.67 & 13.80 & 13.00 & 2.29 & 0.89 & 29.53 & 4.15 & 14.23 & 2.17 \\
\hline \multicolumn{2}{|l|}{ Mean } & 33.02 & 29.25 & 27.08 & 13.69 & 2.44 & 0.69 & 38.55 & 4.99 & 11.31 & 1.64 \\
\hline \multicolumn{2}{|l|}{ LSD at 0.05} & 0.90 & 1.80 & 1.40 & 1.44 & 0.19 & 0.06 & 1.58 & 0.49 & 0.89 & 0.06 \\
\hline \multicolumn{12}{|c|}{ Season 2014-2015 } \\
\hline \multicolumn{2}{|l|}{ Splendid } & 36.63 & 29.33 & 33.15 & 16.23 & 2.96 & 0.44 & 50.14 & 5.98 & 8.23 & 1.03 \\
\hline \multicolumn{2}{|l|}{ Starmon } & 33.08 & 32.23 & 25.42 & 14.05 & 2.44 & 0.76 & 44.09 & 5.14 & 13.65 & 1.75 \\
\hline \multicolumn{2}{|l|}{ Rigour } & 33.76 & 33.10 & 30.25 & 14.52 & 2.88 & 0.62 & 36.25 & 4.85 & 10.02 & 1.65 \\
\hline \multicolumn{2}{|l|}{ Jamon } & 30.98 & 34.49 & 15.49 & 12.96 & 2.36 & 0.83 & 30.14 & 4.22 & 14.25 & 2.39 \\
\hline \multicolumn{2}{|l|}{ Mean } & 33.61 & 32.29 & 26.08 & 14.44 & 2.66 & 0.66 & 40.16 & 5.05 & 11.54 & 1.71 \\
\hline \multicolumn{2}{|l|}{ LSD at 0.05} & 1.30 & 1.26 & 1.37 & 0.99 & 0.20 & 0.02 & 2.21 & 0.14 & 0.52 & 0.15 \\
\hline \multicolumn{6}{|c|}{ Source of Variation } & \multicolumn{6}{|c|}{ Combined Analysis } \\
\hline \multirow{2}{*}{ Seasons } & 2013-14 & 33.02 & 29.25 & 27.08 & 13.69 & 2.44 & 0.69 & 38.55 & 4.99 & 11.31 & 1.64 \\
\hline & $2014-15$ & 33.61 & 32.29 & 26.08 & 14.44 & 2.66 & 0.66 & 40.16 & 5.05 & 11.54 & 1.71 \\
\hline \multirow[t]{2}{*}{ LSD at 0.05} & & NS & 0.73 & NS & NS & 0.19 & NS & 1.01 & NS & NS & NS \\
\hline & Splendid & 36.18 & 28.33 & 33.88 & 15.72 & 2.82 & 0.45 & 49.01 & 5.98 & 8.12 & 1.02 \\
\hline \multirow{3}{*}{ Genotpes } & Starmon & 32.90 & 30.22 & 26.58 & 13.71 & 2.38 & 0.76 & 43.95 & 5.11 & 13.51 & 1.72 \\
\hline & Rigour & 33.40 & 31.45 & 31.23 & 13.86 & 2.69 & 0.64 & 34.63 & 4.80 & 9.82 & 1.67 \\
\hline & Jamon & 30.80 & 33.08 & 14.65 & 12.98 & 2.33 & 0.86 & 29.84 & 4.19 & 14.24 & 2.28 \\
\hline \multirow[t]{4}{*}{ LSD at 0.05} & & 0.71 & 0.97 & 0.87 & 0.78 & 0.12 & 0.02 & 1.21 & 0.12 & 0.46 & 0.07 \\
\hline & $\mathrm{S} 1 \times \mathrm{G} 1$ & 35.72 & 27.33 & 34.60 & 15.20 & 2.67 & 0.45 & 47.87 & 5.98 & 8.00 & 1.01 \\
\hline & $\mathrm{S} 1 \times \mathrm{G} 2$ & 32.71 & 28.20 & 27.73 & 13.37 & 2.31 & 0.75 & 43.81 & 5.07 & 13.36 & 1.69 \\
\hline & $\mathrm{S} 1 \times \mathrm{G} 3$ & 33.04 & 29.80 & 32.20 & 13.20 & 2.49 & 0.65 & 33.00 & 4.75 & 9.62 & 1.69 \\
\hline Seasons $x$ & $\mathrm{~S} 1 \times \mathrm{G} 4$ & 30.62 & 31.67 & 13.80 & 13.00 & 2.29 & 0.89 & 29.53 & 4.15 & 14.24 & 2.17 \\
\hline \multirow[t]{4}{*}{ Genotypes } & $\mathrm{S} 2 \times \mathrm{G} 1$ & 36.63 & 29.33 & 33.15 & 16.23 & 2.96 & 0.44 & 50.14 & 5.98 & 8.23 & 1.03 \\
\hline & $\mathrm{S} 2 \times \mathrm{G} 2$ & 33.08 & 32.23 & 25.42 & 14.05 & 2.44 & 0.76 & 44.09 & 5.14 & 13.65 & 1.75 \\
\hline & $\mathrm{S} 2 \times \mathrm{G} 3$ & 33.76 & 33.10 & 30.25 & 14.52 & 2.88 & 0.62 & 36.25 & 4.85 & 10.02 & 1.65 \\
\hline & $\mathrm{S} 2 \times \mathrm{G} 4$ & 30.98 & 34.49 & 15.49 & 12.96 & 2.36 & 0.83 & 30.14 & 4.22 & 14.25 & 2.39 \\
\hline LSD at 0.05 & & NS & NS & 1.23 & NS & NS & 0.03 & NS & NS & NS & 0.10 \\
\hline
\end{tabular}

The combined analysis of data as shown in Table 1 revealed that the treats of leaf length, number of leaves per plant, root diameter, fresh weight of leaves per plant and dry weight of roots per faddan were insignificant effect by seasons. While the characters, root length, root diameter, fresh weight of root per plant and fresh weight of roots per fad. were significant affected by seasons, whereas the mean values of the second season were more than the first season.

The interaction between genotypes and seasons were insignificant for the most characters, except number of leaves per plant and fresh weight of leaves per plant, which were significant affected. Number of leaves per plant for splendid, Starmon and Rigour fodder beat genotypes was significantly decreased at the second season than the first season, while Jamon genotype was significantly increased. The Jamon genotype was significantly decreased of fresh weight leaves per plant at the second season, also indicate that increased number of leaves per plant (Jamon) decreased leaves fresh weight per plant. The obtained data indicate that Jamon genotypes recorded the lowest Number of leaves /plant, while gave the highest Fresh weight of leaves /plant $(\mathrm{kg})$. These results it may be due to the large size of the paper and the increased thickness

The results indicated that Splendid fodder beat genotype is successful and suitable cultivar under New Valley Governorate, also can be used as a valuable source of fodder for cattle, Niazi, et al., 2000 and Salvova et al., 2004. Suitable forage for dairy cows and suitable to make silage, Akyildiz, 1983 and Ozen et al., 1993.

Evaluation of fodder beat genotypes to infection with diseases:

Damping-off, root rot and wilt diseases: 
Four fodder beat genotypes were tested for their relative susceptibly towards damping-off, root rot and wilt diseases under natural infection with soil borne pathogens in New Valley Governorate.

Data in Figs. 1 and 2 show that the four tested genotypes were susceptible towards the soil borne pathogens however there were some variations among them. Both Rigour and Jamon genotypes recorded the highest susceptibility to infection with damping-off disease in both growing seasons, whereas recorded 48.33 and $52.22 \%$ in the first seasons and 50.33 and $54.33 \%$ damping-off in the second season, respectively. While Starmon genotype recoded the lowest dampingoff (28.89 and $24.89 \%$ ) in both seasons, respectively. On contrary, Rigour and Jamon recoded least root rot and wilt severity in both growing seasons, while Starmon gave the highest root rot /wilt severity in both seasons. In Egypt, no references for susceptibility to infection with damping-off and root rot/wilt diseases but some researcher isolated some soil borne pathogens from sugar beet and table beet plants such as Pythium spp., Rhizoctonia solani, Aphanomyces cochlioides, and Phoma betae (Whitney and Duffus, 1986, 2003 and Piszczek, 2004 and Abo-Elnaga, 2006). In NewYork, Pythium ultimum is the primary causal agent of this disease (Martin, et al., 1984) and causes severe economic losses during cool, wet soil conditions. Although $R$. solani is encountered less frequently, it is capable of causing seed and seedling diseases of table beets as well as infecting older plants later in the growing season during drier and warmer soil conditions. Powdery mildew disease:

Four fodder beet genotypes were tested for their susceptibility towards Powdery mildew disease under open field in New Valley Governorate. Data present in Fig. 3 show that the susceptibility to infection with powdery mildew disease in the tested genotypes were different significantly. Splendid and Rigour genotypes were recorded the highest susceptible to infection with powdery mildew in both growing season, where recorded 38.33 and $35.00 \%$ powdery mildew severity in first growing season and 40.12 and $36.25 \%$ in second season, respectively. On the other hand, Jaman genotype was recorded the lowest powdery mildew severity in both growing seasons (16.67 and $12.47 \%$, respectively. As in case of root diseases no researcher recoded the infection with powdery mildew in fodder beet plants but some researcher studied the effect of powdery mildew on sugar beet such as Peter et al. (2009) and Basati et al. (2013).

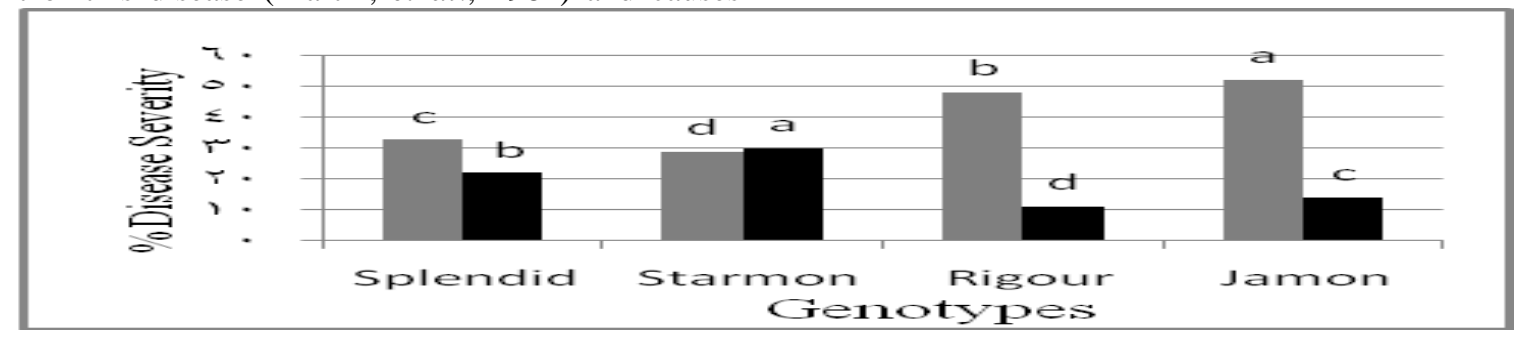

Fig .1. Evaluation of some fodder beet genotypes to damping-off and root rot/ wilt diseases under field conditions during 2013-14 growing season. Different letters indicate significant differences among genotypes within the same colour column according to least significant difference test $(p \leq 0.05)$.

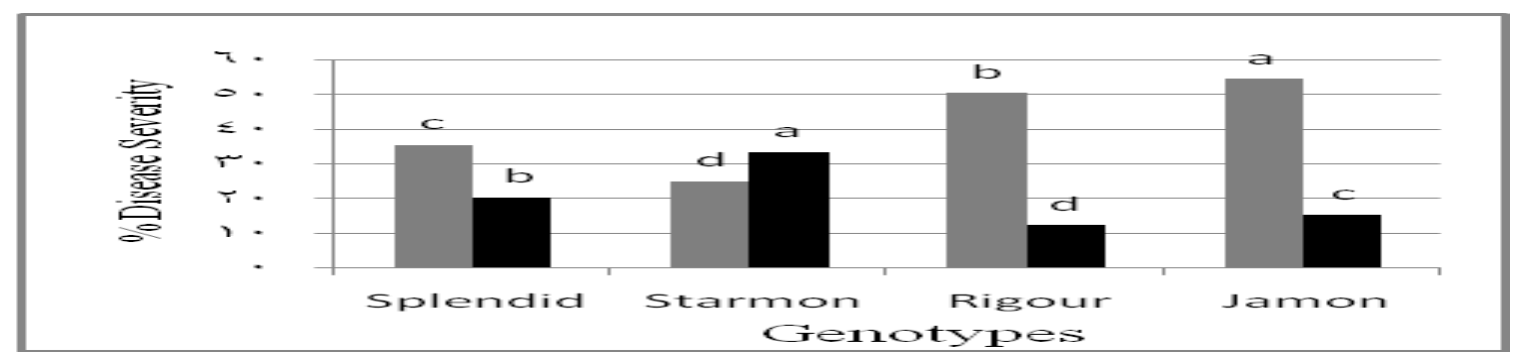

Fig. 2. Evaluation of some fodder beet genotypes to root rot/wilt diseases under field conditions during 2014-15 growing season. Different letters indicate significant differences among genotypes within the same colour column according to least significant difference test $(\mathbf{p} \leq \mathbf{0 . 0 5})$.

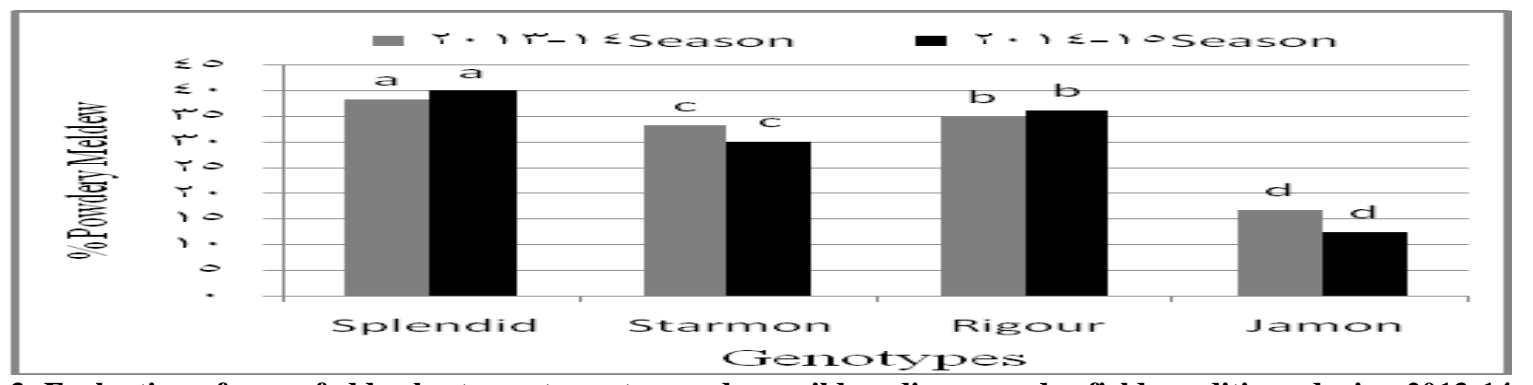

Fig .3. Evaluation of some fodder beet genotypes to powdery mildew disease under field conditions during 2013-14 and 2014-15 growing seasons. Different letters indicate significant differences among genotypes within the same colour column according to least significant difference test $(p \leq 0.05)$. 


\section{Leaf spots disease:}

In this study, the four fodder beet genotypes were tested for their susceptibility towards leaf spots disease under open field in New Valley Governorate. Data in Fig. 4 showed that all tested genotypes were infected with leaf spot disease by moderate degrees. The susceptibility to infection with leaf spot disease in the tested genotypes was varied. Starmon and Splendid genotypes were recorded the highest percentage of infection with leaf spot disease in both growing season, where recorded 22.15 and $20.15 \%$ leaf spot severity in first growing season and 24.15 and $20.00 \%$ in second season, respectively. On the other hand, Rigour and Jaman genotypes were recorded the lowest leaf spot severity in both growing seasons (14.25 and $10.48 \%$, respectively in first season and $12.36,9.16 \%$ leaf spot severity in second season, respectively. As in case of powdery mildew disease no researcher recoded the infection with leaf spot in fodder beet plants but some researcher studied the effect of powdery mildew on sugar beet such as Whitney and Duffus (1986), Larson (2004) and Gado (2007).

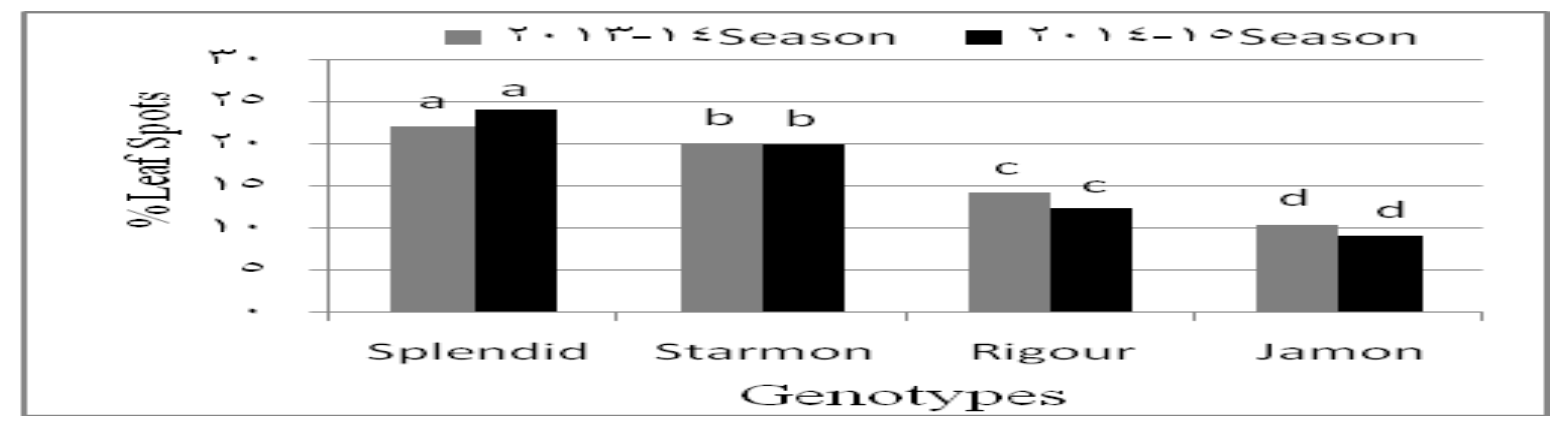

Fig .4. Evolution of some fodder beet genotypes to leaf spots disease under field conditions during 2013-14 and 2014-15 growing seasons. Different letters indicate significant differences among genotypes within the same colour column according to least significant difference test $(p \leq 0.05)$.

\section{CONCLUSION}

Based on the results obtained in the study focusing on the yielding properties and susceptibility to infection with diseases of four genotypes of fodder beet genotypes grown under four locations in different environmental conditions in Egypt, the following conclusions can be drawn:

1. The tested genotypes of fodder beat were significantly different for yield characteristics viz. average of leaf length, root length, number of leaves/plant and root diameter and yield components viz. fresh and dry weights of roots and leaves/plant and total fresh as well as dry weight of root and leaves / fed.

2. Some the tested characteristics of yield and yield components were significantly varied in both growing seasons.

3. The tested genotypes were varied to susceptibility to infection with diseases viz. damping-off, root rot/wilt, powdery mildew and leaf spots under natural infection in field.

\section{REFERENCES}

Abdel -Naby, Z. M; W. W. M. Shafie; A. M. Sallam; S.M. El-Nahrawy and M. F. Abdel-Ghawad (2014). Evaluation of seven fodder beet genotypes under different Egyptian ecological conditions using regression, cluster models and variance measures of stability. Int. J. Curr. Microbiol. App. Sci., 3(4): 1086-1102.

Abdou El-S.; H.M. Abd-Alla and A.A. Galal, (2001). Survey of sesame root rot/wilt disease in Minia and their possible control by ascorbic and salicylic acids. Assuit J. Agric. Sci., 32: 135-152.
Abo-Elnaga, H. G. (2006). Bacillus subtilis as a biocontrol agent for controlling sugar beet damping-off disease. Egypt. J. Phytopathol., 34 (1): 51-59.

Akhileshwari S. V., Amaresh Y. S., Kantharaju V., Shankergoud I. (2012). M. V. RAVIField evaluation of fungicides against powdery mildew of sunflower. Karnataka J. Agric. Sci.,25 (2) : 278-280 .

Akyildiz, A. R. (1983). Yemler Bilgisi ve Teknolojisi. Ankara Univ . Ziraat Fak. No: 868. (C.F. CD Computer Search).

Antonov, I. and A. Zakhariev (1994). State and problems of sugar variety with high productivity on areas both infected and non- beet breeding in Bulgaria. Plant Sciences, 3-4: 97-101.

Basati J.; M. Sheikh Aleslami; A. Jalilian; A. Nemati and Habib Khodaei A. (2013).Development of diploid pollinator resistant to powdery mildew disease in sugar beet. J. of Sugar Beet, 29(1):1-7.

DAF (Department of Agriculture and Food) (1998). Root, fodder crop, pulse and oilseed varieties. Irish recommended list. Government Stationary Office, Dublin, $17 \mathrm{p}$.

Gado E.A.M. (2007). Management of Cercospora leaf spot disease of sugar beet plants by some fungicides and plant Extracts. Egypt. J. Phytopathol., 35 (2): 1-10.

Gomez, K.A and A.A. Gomez (1984). Statistical Procedures for Agricultural Research. A. Lviley. Interscience Publication. New York, pp: 678.

Harveson, R.M.; L.E. Hansen and G. L. Hein (2009). Compendium of Beet Diseases and Pests, 2nd. American Phytopathological Society Press, St. Paul. 
Kikindonov, G. (2012). Stability of productiveness and technological qualities of diploid and triploid sugar beet varieties and hybrids. Agricultural Science and Technology, 4 (3): 201202.

Larson, B.J. (2004). Integrated management of Cercospora leaf spot on sugar Beet. M. Sc. Thesis, Plant Pathology, Montana State University Bozeman, Montana.

Liu, L., J.W. Kloepper and S.Tuzun (1995). Introduction of systemic resistance in cucumber against Fusarium wilt by plant growth-promoting rhizobacteria. Phytopathology, 85: 695-698.

Martin, S. B.; G. S., Abawi and H.C. Hoch (1984). Influence of the antagonist Laetisaria arvalis on infection of table beets by Phoma betae. Phytopathology, 74:1092-1096.

MSTAT-C. (1991). A Software Program for the Design, Management and Analysis of Agronomic Research Experiments. Michigan State University: pp: 400.

Niazi, B.H., J. Rozema, R.A. Broekman and M. Salim (2000). Dynamics of growth and water relations of fodder beet and sea beet in response to salinity. J. Agronomy and Crop Science, 184: 101-109.

Ozen, N., A. Cakir; S. Hasimoglu and S. Aksoy (1993). Yemler Bilgisi ve Yem Teknolojisi Ders Notlarý: 50. Ataturk Univ . Erzurum (C.F. CD Computer Search).
Peter F.J. Wolf, R.L., B. Katja, V. Joseph-Alexander (2009). Quaternary integrated pest management concept for powdery mildew in sugar beet. III. Economic damage threshold and loss prediction. J. Für Kulturflanzen, 61 (3): 91-97.

Piszczek J. (2004). Occurrence of root rot of sugar beet genotypes. J. of Plant Protection Res. 44 (4):343345.

Slavova, Y., D. Nenkova and I. Ivanova (2004). Optimization of nutritive medium with the purpose of rooting of fodder beet (Beta vulgaris L. var. crassa). Bulg. J. Agric. Sci., 10: 465-468.

Weiland, J.J. (2000). A survey for the prevalence and distribution of Cercospora beticola tolerant to triphenyltin hydroxide and mancozeb and resistant to thiophanate methyl in 1999. 1999 Sugarbeet Res. Ext. Rep. 30: 236- 239.

Wheeler, B.E.J. (1969). An Introduction to Plant Diseases, John Wiley and Sons Limited, London, P. 301.

Whitney, E.D. and J.E. Duffus (Eds.). (1986). Compendium of Beet Diseases and Insects. APS Press, The American Phytopathological Society, St. Paul.

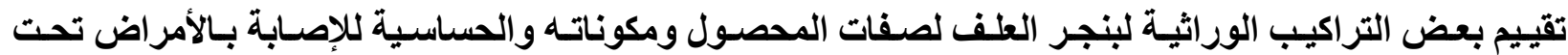 ظروف الوادى الجديا

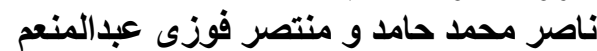

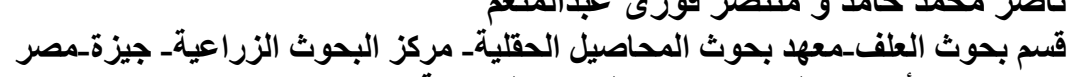

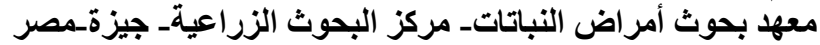

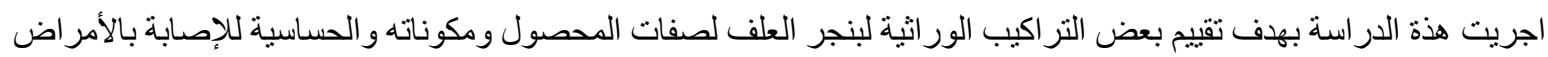

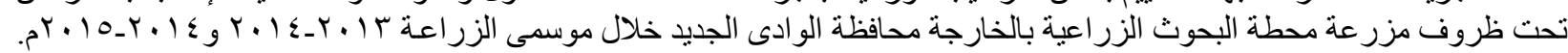

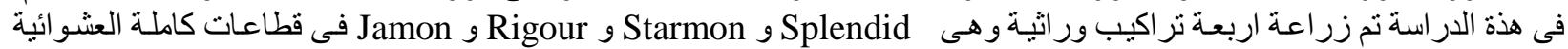

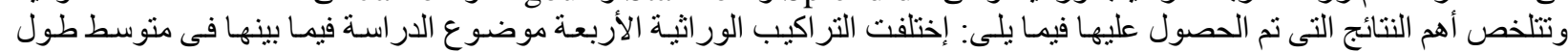

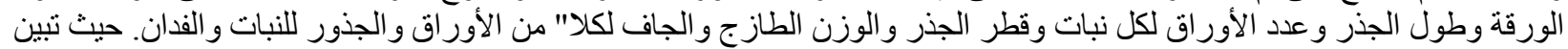

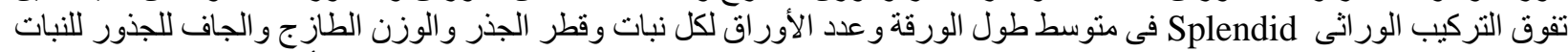

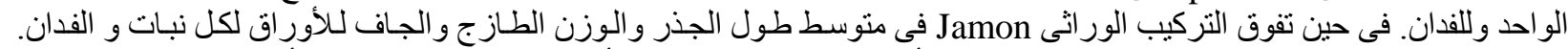

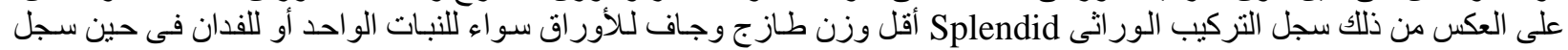

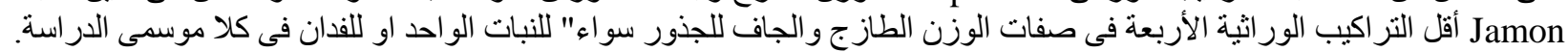

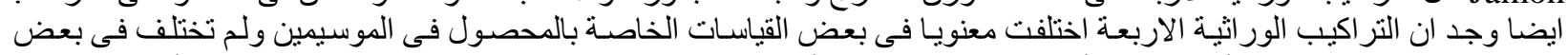

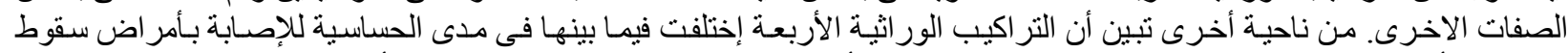

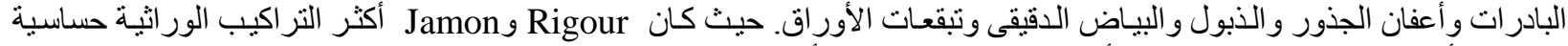

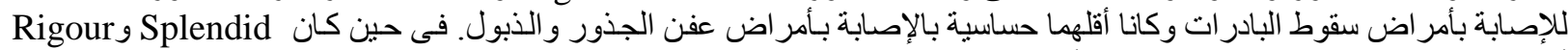

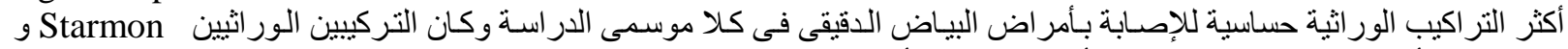

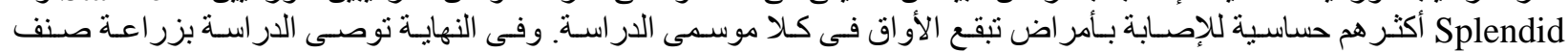

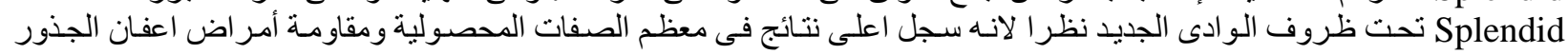
و الذبول. 